Limnological Review (2013) 13, 3: 147-153

DOI 10.2478/limre-2013-0016

\title{
Water level fluctuations in selected Wielkopolski National Park lakes in 2012 against changes noted in 2007-2008
}

\author{
Michał Lorenc ${ }^{1}$, Renata Dondajewska ${ }^{2}$, Lech Kaczmarek ${ }^{1}$ \\ ${ }^{1}$ Adam Mickiewicz University, Jeziory Ecological Station, PO Box 40, 62-050 Mosina, Poznań, Poland, e-mail: michall@amu.edu.pl \\ (corresponding author) \\ ${ }^{2}$ Adam Mickiewicz University, Faculty of Biology, Department of Water Protection, Umultowska 89, 61-614 Poznań, Poland
}

\begin{abstract}
The results presented in this paper of water level fluctuations in selected lakes of Wielkopolski National Park have a preliminary character, contributing new information to the knowledge on this area. Five lakes situated in three distinct tunnel valleys were selected for research: Jarosławieckie, Góreckie, Budzyńskie, Witobelskie and Łódzko-Dymaczewskie. The water level was measured from December 2006 till January 2008 and from January till December of 2012 with ca. monthly frequency. An increase in the water stage was noted in the autumn-winter period, which was rather unusual. The comparison of years 2007 and 2012 indicated higher water levels in the latter. The amplitude of the water level was higher in flow-through lakes due to the reaction to precipitation in early spring as well as different catchment features. Specific water level fluctuations in Lake Góreckie are probably related to the influence of groundwater of the Wielkopolska fossil valley.
\end{abstract}

Key words: lakes, water level fluctuations, Wielkopolski National Park

\section{Introduction}

Natural variability in lake water level is determined by many factors, including the most important meteorological features such as precipitation and air temperatures (Dąbrowski 2004). Individual properties of lake catchment as well as water management shape the visibility of natural water level fluctuations (Dąbrowski and Węglarczyk 2005). Changes in water stage influence the area, depth and retention capacity of lakes (Michalczyk et al. 2011); however lake reaction to water inflow from different sources is characterized by hydrologic inertia, and therefore long-term studies are crucial as well as consideration of both climatic and local factors (Choiński 2007). From this point of view, the results presented of water level fluctuations in selected lakes of Wielkopolski National Park have a preliminary character, contributing new information to the knowledge on this area.

\section{Study area and methods}

Wielkopolski National Park (WNP) is situated in western Poland, $10 \mathrm{~km}$ south-west of Poznań. An area of approximately 15,000 ha has been protected as a national park and its protected buffer zone since 1957. The above area is located in the Poznan Lakeland and covers almost 70 water bodies of various types, including lakes, intermittent and man-made reservoirs (Fig. 1). The majority of them are non-outflow lakes with various surface areas and water volume (Szyper and Gołdyn 2002). Natural water bodies are of glacial origin, therefore as remnants of subglacial rivers they are situated in four characteristic channels - tunnel valleys of NW-SE orientation (Fig. 1). The morphometric and hydrographic features of the studied lakes and their catchment areas are given in Tables 1 and 2 .

The Górecko-Budzyński tunnel valley comprises lakes Góreckie, Skrzynka, Kociołek and Budzyńskie, var- 


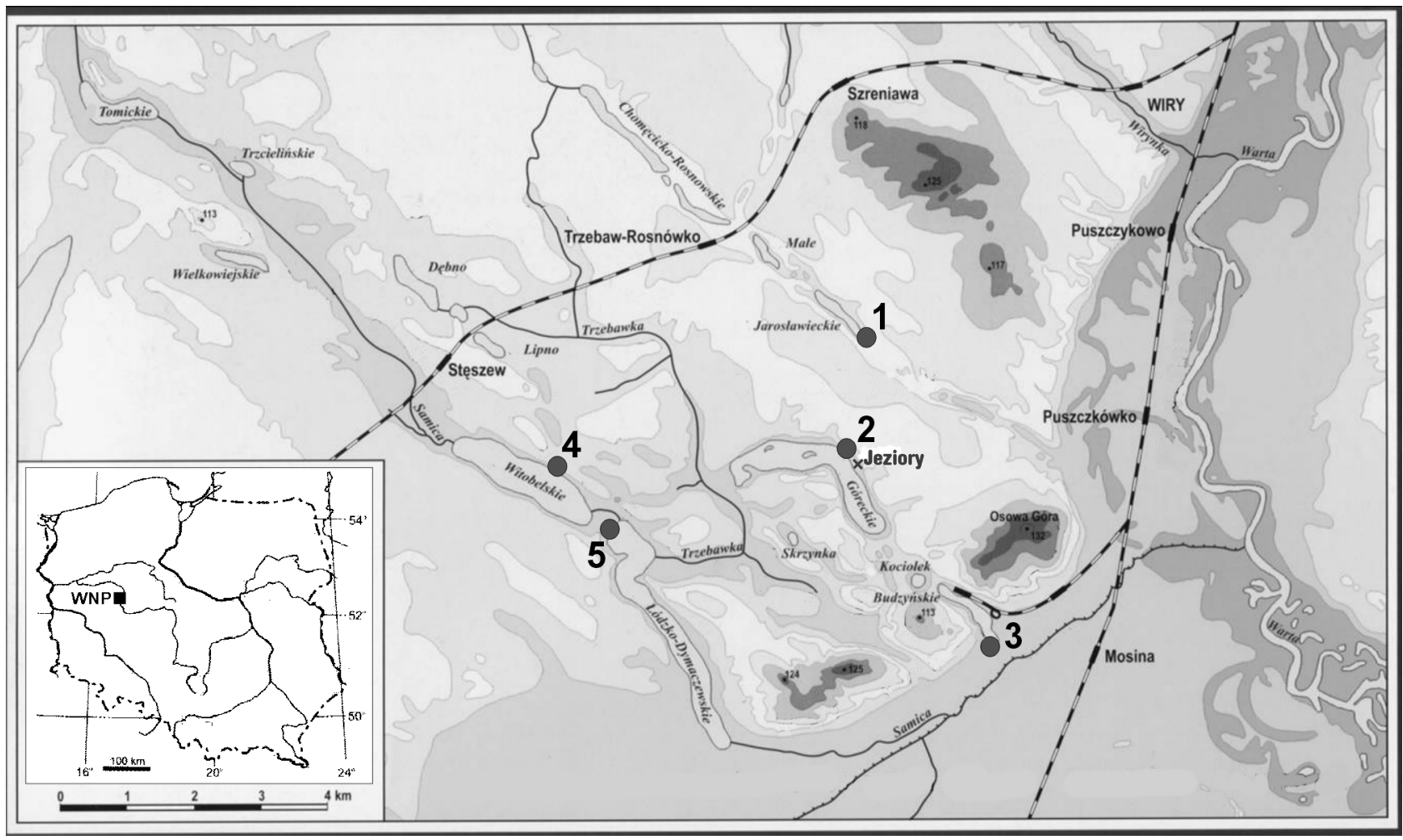

Fig. 1. Location of the studied lakes and the points of measurement (physical map of the WNP acc. to Wyczyński and Wyczyńska 2006): 1 - Jarosławieckie, 2 - Góreckie, 3 - Budzyńskie, 4 - Witobelskie, 5 - Łódzko-Dymaczewskie

Table 1. Morphometric and hydrographic features of the studied lakes in Wielkopolski National Park (after Szyper and Gołdyn 2002 and Kolendowicz et al. 2008)

\begin{tabular}{|c|c|c|c|c|c|c|}
\hline Lake & Surface [ha] & Volume $\left[\times 10^{3} \mathrm{~m}^{3}\right]$ & Max depth [m] & Mean depth [m] & Hydrographic relations & Ohle index \\
\hline Góreckie & 101.0 & 9340.0 & 16.6 & 8.5 & non-outflow & 6.6 \\
\hline Budzyńskie & 11.0 & 154.0 & 2.7 & 1.4 & non-outflow & 6.2 \\
\hline Łódzkie & 119.6 & 6220.5 & 12.0 & 5.3 & flow-through & 29.1 \\
\hline Witobelskie & 100.3 & 1705.1 & 3.7 & 1.7 & flow-through & 42.9 \\
\hline Jarosławieckie & 11.2 & 412.2 & 6.6 & 3.7 & non-outflow & 85.1 \\
\hline
\end{tabular}

Table 2. Land use in the catchment areas (after Szyper et al. 2001)

\begin{tabular}{lcccccc}
\hline Lake & Catchment area [ha] & Forest [\%] & Arable fields [\%] & Meadows [\%] & Built-up areas [\%] & Waters [\%] \\
\hline Góreckie & 671.0 & 52.0 & 47.7 & - & 0.3 & - \\
\hline Budzyńskie & 68.5 & 50.4 & 34.3 & 11.7 & 2.2 & 1.4 \\
\hline Łódzkie & 3483.5 & 33.8 & 54.7 & 9.2 & 2.0 & 0.3 \\
\hline Witobelskie & 4302.5 & 10.9 & 76.3 & 8.3 & 4.1 & 0.4 \\
\hline Jarosławieckie & 953.0 & 58.7 & 40.7 & 0.2 & 0.2 \\
\hline
\end{tabular}


ying significantly in morphometric features. The length of this tunnel valley reaches $5.3 \mathrm{~km}$, while the width measures up to $300 \mathrm{~m}$. The Witobelsko-Dymaczewski tunnel valley is the longest in WNP, reaching $13.6 \mathrm{~km}$ and up to $570 \mathrm{~m}$ in width. Witobelskie and Łódzko-Dymaczewskie (abbrev. Łódzkie,) lakes are fed by the River Samica. Part of this channel is covered by three small lakes, considered in some publications as a separate tunnel valley (lakes Bochenek, Lipno and Dębno) (Szyper et al. 2001; Szyper and Gołdyn 2002). The Rosnowsko-Jarosławiecki tunnel valley with its length of $6.1 \mathrm{~km}$ and width up to 200 m contains Chomęcickie, Rosnowskie Duże, Małe and Jarosławieckie lakes (Walna et al. 2011).

Five lakes situated in three distinct tunnel valleys were selected for research: Jarosławieckie, Góreckie, Budzyńskie, Witobelskie and Łódzko-Dymaczewskie. The water level was measured from December 2006 till January 2008 and from January till December of 2012 with ca. monthly frequency. Dates of particulate measurements do not correlate with calendar months; therefore the results are given in relation to research periods and meteorological seasons. Measurements were conducted based on the benchmark network with the use of a total station. Precipitation was registered automatically in Jeziory Ecological Station situated in Wielkopolski National Park.

\section{Results}

The character of water level changes in the annual cycle.

Water level fluctuations in particular measurement periods and in meteorological seasons are presented in figures 2 and 3 . These changes were correlated with precipitation in the same time intervals and supplemented with water level changes in relation to the benchmark (Fig.4) as well as values of total amplitudes and water balance included in Table 3 . The analysis of results indicated the following phenomena:

1. In autumn, winter and early spring (October-April) an increase in water level dominated in the studied lakes. During winter (January-March) of all years a distinct growth was noted in all reservoirs. In autumn (October-December) a similar tendency was noted, with the exception of Lake Góreckie, where a small decrease was observed, as well as in Jarosławieckie Lake in 2012.

2. A drop in water level was noted in spring and summer (April till October). Short-term growth in some of the analysed lakes was related to greater precipitation. Such a situation was observed between $7^{\text {th }}$ May and $8^{\text {th }}$ June 2007 in three lakes
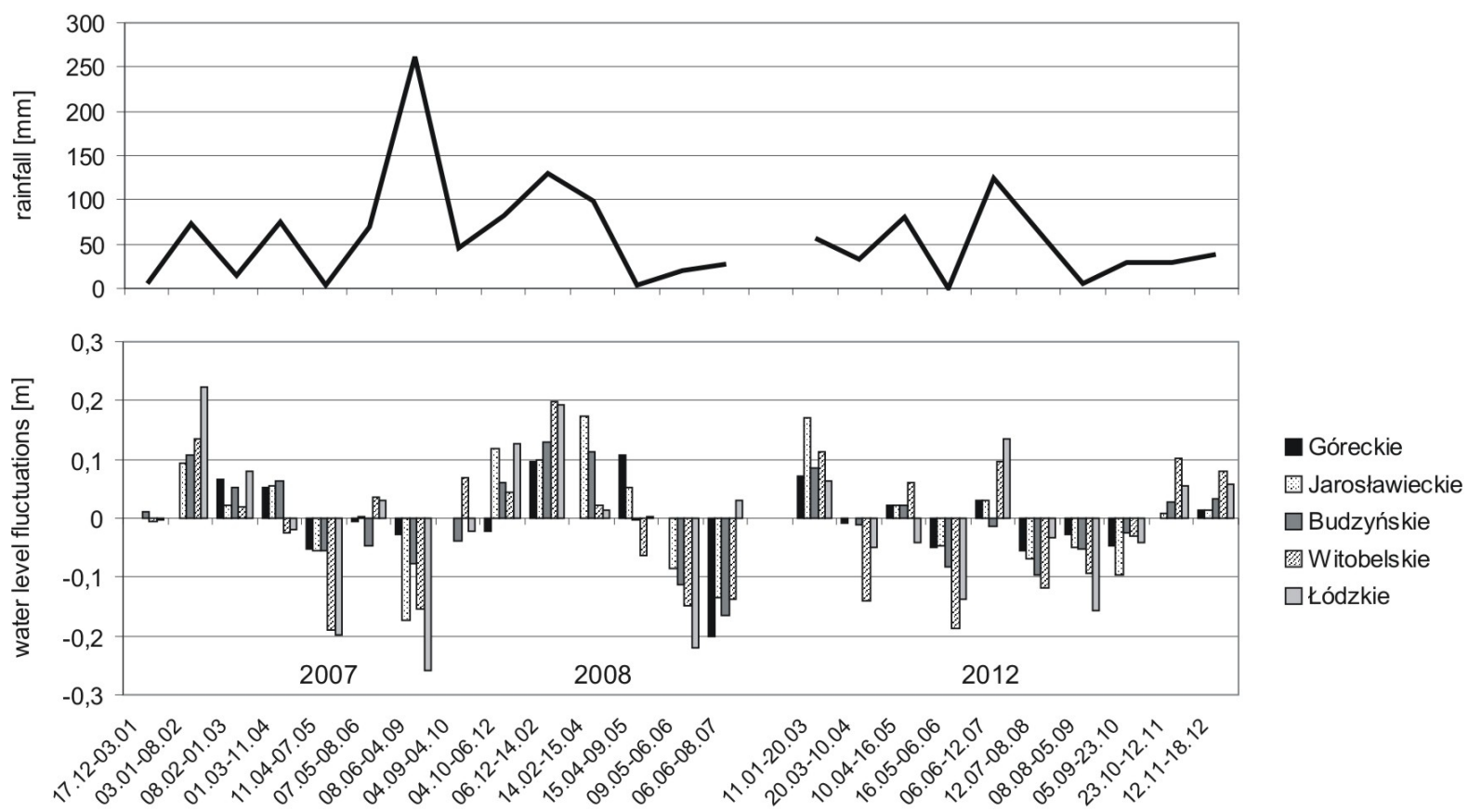

Fig. 2. Water level fluctuations and precipitation in particular measurement periods. Lack of data for Góreckie Lake from: 04.09.2007, 15.04.2008 and 06.06.2008. For this reason in case if this lake the diagram shows data for the following time intervals: 04.09-06.12.2007; 14.02-09.05.2008 and 09.05-08.07.2008. Lack of data also for Jarosławieckie Lake from 04.10.2007, and the diagram shows changes noted between 04.09 and 06.12.2007. 


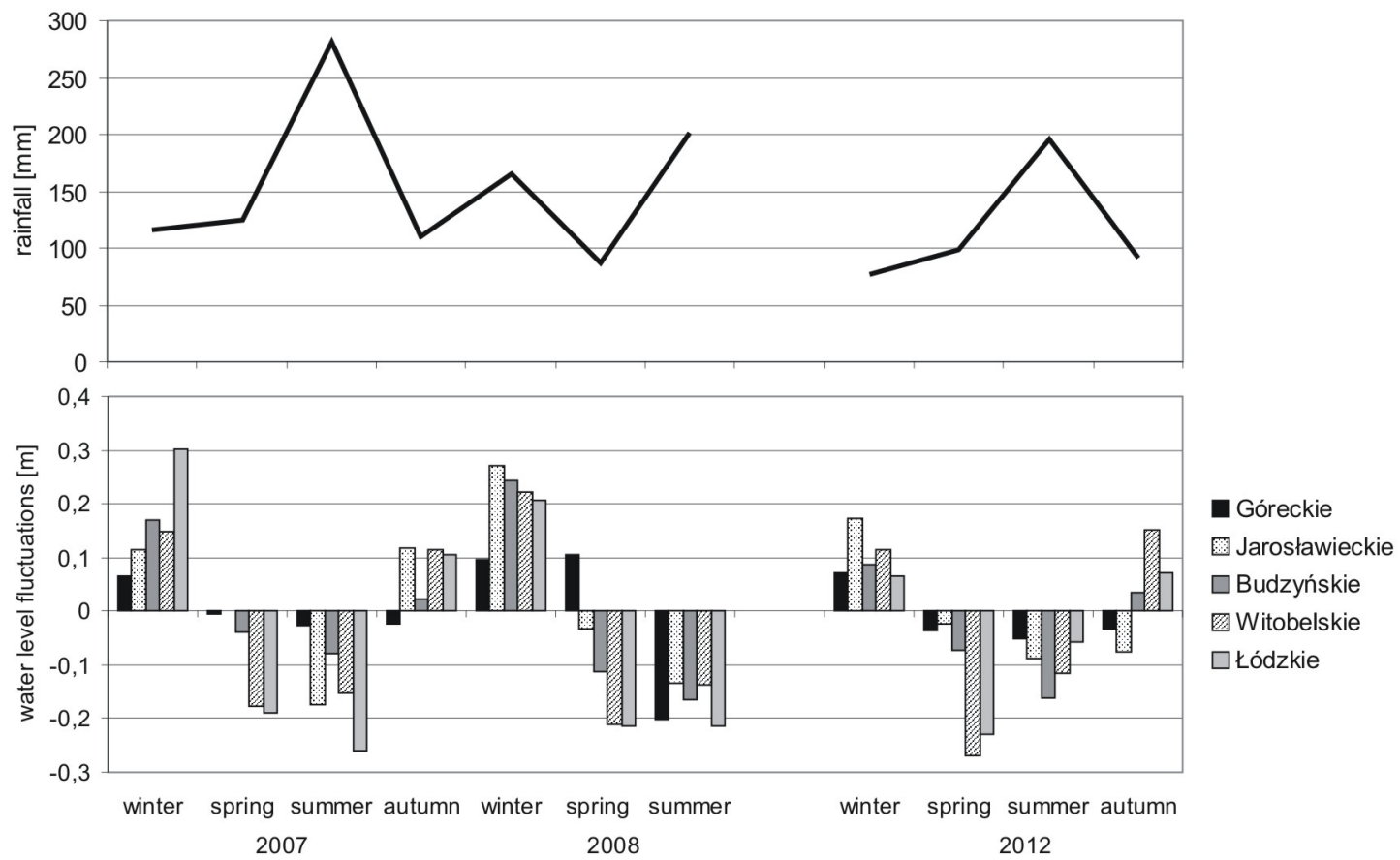

Fig. 3. Changes in water level and precipitation in meteorological seasons. Measurement periods in relation to meteorological seasons: 2007: winter 17.12-01.03; spring 01.03-08.06; summer 08.06-04.09, autumn 04.09-06.12; 2008: winter 06.12-15.04; spring 15.04-06.06; summer 06.06-08.07; 2012: winter 11.01-20.03; spring 20.03-06.06; summer 06.06-05.09, autumn 05.09-18.12. For Góreckie Lake the diagram shows changes noted between: 06.12.2007-14.02.2008 and 14.02.-09.05.2007 (see information to Fig.2).

2007

2008
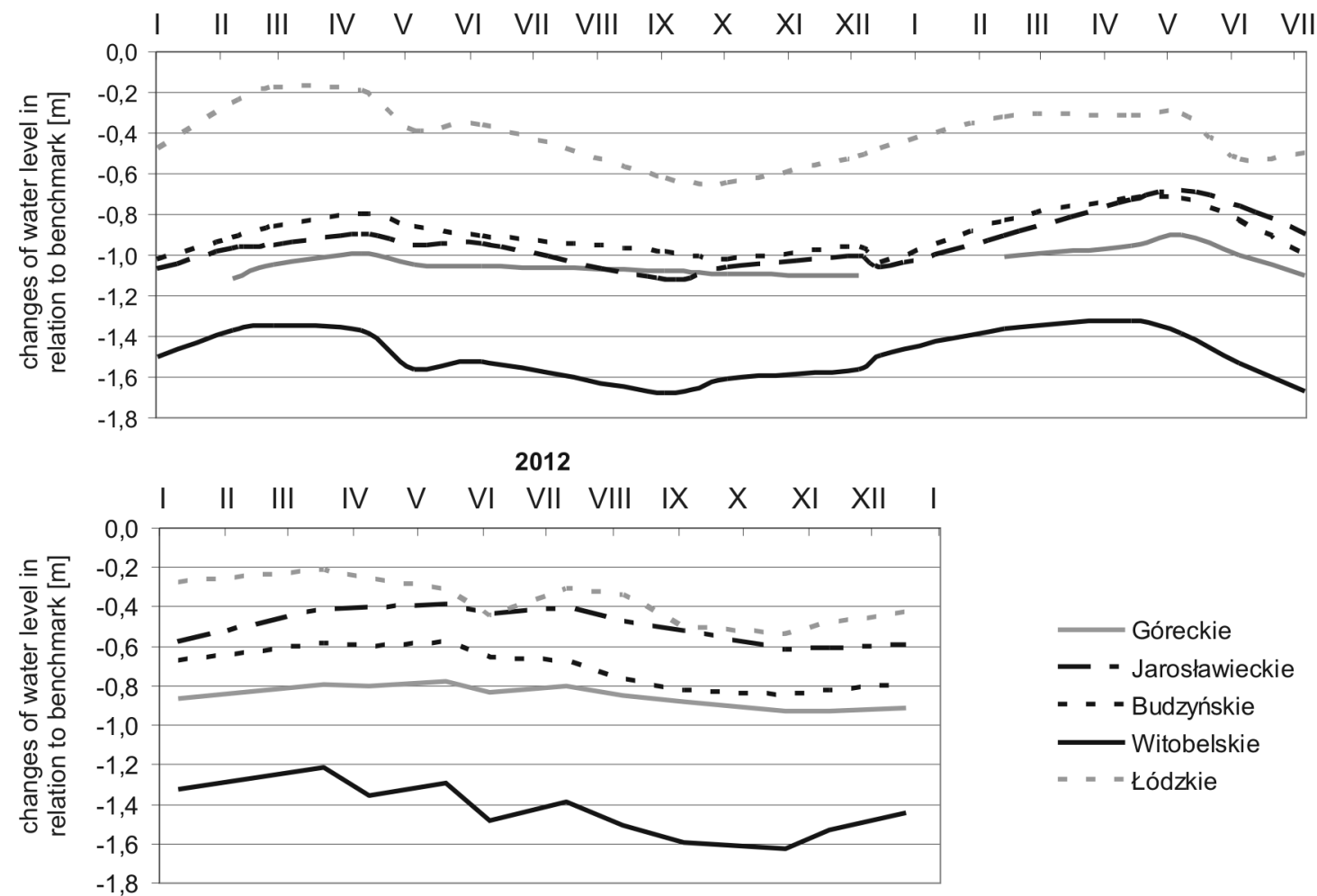

Fig. 4. Changes in water level in the years 2007-2008 and in 2012 in relation to the benchmark 
(Jarosławieckie, Witobelskie, Łódzkie), $10^{\text {th }}$ April and $16^{\text {th }}$ May 2012 in all lakes apart from Łódzkie and between $6^{\text {th }}$ June and $12^{\text {th }}$ July 2012 in all lakes apart from Budzyńskie. In 2008 a continuous high spring water level was registered for longer - up to May - relating to precipitation. A water level increase in Lake Łódzkie was recorded .from $6^{\text {th }}$ June till $8^{\text {th }}$ July, with no parallel in other lakes but correlate with the higher amount of precipitation.

3. A progressive increase in water level in the autumn-winter period and early spring results in the highest levels noted in non-outflow lakes in April (2007) and May (2012). In flow-through lakes it was noted earlier - always in March (Fig. 4, Tab. 3). The lowest water level was observed in autumn (usually October), apart from Góreckie and Budzyńskie lakes in 2007 (January-February).

4. Various amplitudes of water level were observed in the analysed lakes. Similar values were noted in Jarosławieckie and Budzyńskie lakes in 2007 and 2012. The lowest amplitudes but also similar in the analyzed years occurred in Góreckie Lake. In two flow-through lakes (Witobelskie and Łódzkie) the amplitude of water level changes was distinctly greater in comparison with other lakes as well as the difference between the year 2007 and 2012.

5. The balance of water level fluctuation in 2007 and 2012 also differentiated the lakes. In 2007 it was positive in all non-outflow lakes and negative in flow-through lakes. In 2012 the negative balance was noted in all studied lakes. A considerable decrease in water level was found in flow-through lakes in 2012, reaching over a dozen $\mathrm{cm}$. Only in Budzyńskie - among non-outflow lakes - the decrease was similar.

6. The water level was higher in all lakes in 2012 in comparison with 2007 and 2008. It was notably observed in Lake Jarosławieckie - an increase of 40 $\mathrm{cm}$. Lower values characterized other lakes $-\mathrm{ca} .20$ cm (Fig. 4).

The correlation of water level fluctuations with precipitation

Two important results were noted during analysis of meteorological data:

1. Water level changes, both in particular measurement periods and in meteorological seasons, did not link to precipitation in 2007. Only in autumn was this trend noted - both an increase in water level and in rainfall.

2. A more distinct relation between water level and precipitation was noted in 2008 and 2012; however, discrepancies were noted in summer, when the precipitation did not compensate for water loss during evaporation.

Table 3. Annual amplitude and water level balance in the years 2007 (03.01-06.12) and 2012 (11.01-18.12). In case of Góreckie Lake the data from 2007 refer to shorter time span (08.02-06.12)

\begin{tabular}{|c|c|c|c|c|c|c|}
\hline \multirow{3}{*}{ Lake } & \multicolumn{3}{|c|}{2007} & \multicolumn{3}{|c|}{2012} \\
\hline & $\begin{array}{l}\text { Highest and } \\
\text { lowest water } \\
\text { level in relation to } \\
\text { benchmark } \\
\text { with month of its } \\
\text { occurrence }\end{array}$ & $\begin{array}{l}\text { Amplitude of water } \\
\text { level changes }\end{array}$ & $\begin{array}{l}\text { Balance of } \\
\text { water level } \\
\text { changes }\end{array}$ & $\begin{array}{l}\text { Highest and } \\
\text { lowest water } \\
\text { level in relation to } \\
\text { benchmark } \\
\text { with month of its } \\
\text { occurrence }\end{array}$ & $\begin{array}{c}\text { Amplitude of } \\
\text { water level } \\
\text { changes }\end{array}$ & $\begin{array}{c}\text { Balance of } \\
\text { water level } \\
\text { changes }\end{array}$ \\
\hline & \multicolumn{6}{|c|}{$[\mathrm{mm}]$} \\
\hline Jarosławieckie & $\begin{array}{c}\text {-1122 September* } \\
-897 \text { April }\end{array}$ & 225 & +62 & $\begin{array}{c}-619 \text { October } \\
-385 \text { May }\end{array}$ & 234 & -17 \\
\hline Góreckie & $\begin{array}{l}\text {-1114 February } \\
\text {-995 April }\end{array}$ & 119 & +12 & $\begin{array}{c}-926 \text { November } \\
-779 \text { May }\end{array}$ & 147 & -48 \\
\hline Budzyńskie & $\begin{array}{l}-1025 \text { January } \\
-802 \text { April }\end{array}$ & 223 & +63 & $\begin{array}{l}-850 \text { October } \\
-579 \text { May }\end{array}$ & 271 & -114 \\
\hline Witobelskie & $\begin{array}{c}-1677 \text { September } \\
\text {-1346 March }\end{array}$ & 331 & -60 & $\begin{array}{l}-1626 \text { October } \\
-1212 \text { March }\end{array}$ & 414 & -121 \\
\hline Łódzkie & $\begin{array}{l}-644 \text { October } \\
-176 \text { March }\end{array}$ & 468 & -39 & $\begin{array}{l}-540 \text { October } \\
-215 \text { March }\end{array}$ & 325 & -148 \\
\hline
\end{tabular}

* Lack of data from October, when the lowest water level was very probale 


\section{Discussion}

The results indicating an increase in water level during the autumn-winter period are rather unusual. The role of these seasons in the replenishment of water resources in lakes has already been stated (eg. Górniak and Piekarski 2002; Michalczyk et al. 2011); however, they influence the increase in water level in early spring (from March). This trend observed in earlier months (October-February) was rather unexpected as usually water levels in reservoirs decrease from the beginning of the hydrological year up to January-February. The precipitation may be partially responsible for this phenomenon as well as snow melting during rather mild winters. A statistically significant relationship between the amount of snowfall in the December-March period and the amplitude of water level changes in the November-April period was noted by Górniak and Piekarski (2002) for lakes in northwestern Poland. Additional analysis of the results gained against the background of supplementary meteorological data is required to explain thoroughly this tendency.

Maximum water level was noted in flowthrough lakes in March, unlike in non-outflow lakes (April-May). The increase of water level in flowthrough lake is to some degree determined by Samica River, feeding the Witobelskie and Łódzkie lakes with water flowing from the greatest catchment among the analysed lakes. Additionally, it is dominated by arable fields, stimulating surface runoff, as do the steep slopes of the tunnel valleys in which the lakes are situated. A relationship between the seasonal variability of the water level in lakes with a semi-natural catchment and the snowfall in the December-March period was found for lakes in the northwestern part of Poland (Górniak and Piekarski 2002). The reaction of other lakes is delayed in time due to a few factors: lack of surface inflow, smaller catchment area, and greater contribution of forest in the catchment (over 50\%). The occurrence of the lowest water levels in autumn has already been observed in other lakes in Poland (Górniak and Piekarski 2002).

Significant differences in amplitudes of water level changes between the analysed lakes might be explained by the sources of water inflow, morphometric features and catchment character. Jarosławieckie and Budzyńskie lakes, outstanding in similar amplitudes in both years, have comparable lake surface area and mean depth as well as the share of forest and arable fields in the catchment. Lakes with a small catchment are usually more resistant in their reaction to the variability of climatic factors such as precipitation and temperature (Dąbrowski and Węglarczyk 2005). Both lakes are non-outflow and as they are relatively shallow are not fed by ground-water from deeper aquifers.

The distinctly greater water level amplitude in Witobelskie and Lódzkie lakes is a consequence of its flow-through character as well as their quite high lake surface area, low mean depth, and the small proportion of forest areas in the catchment, favouring water evaporation (low water levels in September and October). The rhythm of water level fluctuations in flowthrough lakes is much more related to the upper part of the catchment than to the direct catchment (Dąbrowski 2004). Conditions leading to maximum water stages in these lakes in March have already been mentioned.

In case of Góreckie Lake hydraulic connection with ground-water of the Wielkopolska fossil valley is possible (Górski and Przybyłek 2003), shaping the water level of the lake (Kolendowicz et al. 2008). The study in this field indicated no influence of precipitation on water level (Kolendowicz et al. 2009). According to the literature, the relation of water level with drainage by aquifers is typical for deep non-outflow lakes (Choiński 2007), whilst the influence of precipitation is crucial only when it exceeds evaporation.

It is worth noticing that the balance of water level fluctuations was different in the analysed lakes in the years 2007 and 2012. More thorough analysis, based on other meteorological data, is required as well as the analysis of the external loading sources to explain this phenomenon. In the light of reports on the year-long delay in the reaction of lakes to an increase or decrease in precipitation, resulting from research in the Łęczna-Włodawa Lakeland (Michalczyk et al. 2011), it is indispensable to continue the measurement in Wielkopolski National Park.

A significant conclusion coming from the research conducted was the increase in water level in all lakes in 2012 in comparison to 2007, reaching usually $20 \mathrm{~cm}$ and even $40 \mathrm{~cm}$ (Jarosławieckie Lake). Measurements taken in the period April-July 2013 (not included in this paper) indicate a further increase of the water level. This is a valuable observation due to the fact that many lakes in the Wielkopolsko-Kujawskie Lakeland are characterized by a multiannual decrease in water level (Nowacka and Ptak 2007). The development of a zone of emerged macrophytes along the lake shores is a visible symptom of these changes. 
The relationship between water level changes and precipitation varies annually and should be considered against the variability of other factors shaping the water level. The continuation of research in this area, including more thorough analysis of the results gained, should provide a more complete results.

\section{Conclusion}

Water level fluctuations in the analyzed lakes were characterized by two distinct results: (i) an increase noted in the autumn-winter period and (ii) greater water stages in 2012 in comparison with 2007. The amplitude of the water level was higher in flowthrough lakes due to the reaction to precipitation in early spring as well as different catchment features. Water level fluctuations in Góreckie Lake are probably related to the influence of the ground-water of the Wielkopolska fossil valley. Further research and analysis of the results against a wide range of environmental factors are justified.

\section{References}

Choiński A., 2007, Limnologia fizyczna Polski (Physical limnology of Poland), Wyd. Nauk. UAM, Poznań, p. 550 (in Polish).

Dąbrowski M., 2004, Trends in changes of lake water levels in the Pomerania Lakeland, Limnol. Rev. 4: 75-80.

Dąbrowski M., Węglarczyk S., 2005, Cyclical nature of fluctuations in the levels of lakes of Northern Poland, Limnol. Rev. 5: 61-67.

Górniak A., Piekarski K., 2002, Seasonal and multiannual changes of water levels in lakes of northeastern Poland, Pol. J. Environ. Stud. 11(4): 349-354.

Górski J., Przybyłek J., 2003, Problemy zagrożenia i ochrony wód podziemnych na terenie Wielkopolskiego Par$\mathrm{ku}$ Narodowego (Problems of threats to and protection of ground-water on the area of Wielkopolski National Park), Morena 10: 59-72 (in Polish).

Kolendowicz L., Hanke J., Kaczmarek L., Lorenc M., 2008, Zmiany poziomu wody Jeziora Góreckiego (Wielkopolski Park Narodowy) w latach 2002-2007 na tle wahania poziomu wód wielkopolskiej doliny kopalnej w warunków atmosferycznych (Changes in the water level of Lake Góreckie (Wielkopolski National Park) in the years 2002-2007 in comparison with fluctuations in the water level of the Wielkopolska fossil valley and atmospheric conditions), [in:] Partyka J., Pociask-Karteczka J. (eds), Wody na obszarach chronionych (Waters of protected areas), IGGP UJ, Ojcowski National Park, PTG, Kraków: 159-168 (in Polish).

Kolendowicz L., Szyga-Pluta K., Hanke J., Kaczmarek L., Lorenc M., 2009, Zmiany poziomu wody w wybranych zbiornikach wodnych Wielkopolskiego Parku Narodowego w latach 2002-2008 na tle wahania poziomu wód podziemnych i warunków atmosferycznych (Changes in water level of selected water reservoirs in Wielkopolski National Park in the years 2002-2008 in comparison with fluctuations in the ground-water level and atmospheric conditions), [in:] Walna B., Kaczmarek L., Lorenc M., Dondajewska R., (eds.), Wielkopolski Park Narodowy $\mathrm{w}$ badaniach przyrodniczych (WielkopolskiNational Park in environmental studies), Wyd. Nauk. UAM, Poznań-Jeziory: 95-107 (in Polish).

Michalczyk. Z., Chmiel S., Turczyński M., 2011, Lake water stage dynamics in the Łęczna-Włodawa Lake District in 1991-2010, Limnol. Rev. 11(3): 113-122.

Nowacka A., Ptak M., 2007, Zmiany powierzchni jezior na Pojezierzu kujawsko-Wielkopolskim w XX w (The change in the surface area of lakes in the Wielkopolsko-Kujawskie Lake District in the 20th century), Bad. Fizjogr. Pol. Zach. A 58: 149-157 (in Polish, English summary).

Szyper H., Gołdyn R., 2002, Role of catchment area in the transport of nutrients to lakes in the Wielkopolski National Park in Poland, Lakes Reserv. Res. Manage. 7(1): 25-33.

Szyper H., Romanowicz W., Gołdyn R., 2001, Zagrożenia jezior Wielkopolskiego Parku Narodowego przez czynniki zewnętrzne (Threat to Wielkopolski National Park lakes by external factors), [in:] Burchardt L. (ed.), Ekosystemy wodne Wielkopolskiego Parku Narodowego (Water ecosystems of the Wielkopolski National Park), Wyd. Nauk. UAM, Poznań: 427-474 (in Polish).

Walna B., Siepak M., Lorenc M., 2011, Wpływ terenów prolnych na chemizm wód zasilających Jezioro Góreckie (Wielkopolski Park Narodowy) (The influence of post-agricultural areas on the chemistry of waters feeding Góreckie Lake (Wielkopolski National Park)), Bogucki Wyd. Nauk., Poznań, p. 137 (in Polish).

Wyczyńska H., Wyczyński J., 2006, Wielkopolski Park Narodowy: biuletyn informacyjny (Wielkopolski National Park: bulletin), Bogucki Wyd. Nauk., Poznań, p. 52 (in Polish). 